\title{
Calcium, copper, manganese and zinc and plant diseases: a review
}

\author{
Eloisa Lorenzetti ${ }^{1 *}$, José Renato Stangarlin ${ }^{2}$, Jeferson Carlos Carvalho ${ }^{2}$, Camila Hendges ${ }^{2}$, Tatiane \\ Calandrino da Mata ${ }^{2}$, Alfredo José Alves Neto ${ }^{2}$, Taís Regina Kohler ${ }^{2}$, Luciano Tartaro ${ }^{1}$, Giovana Ritter ${ }^{2}$, \\ Olivia Diulen Costa Brito ${ }^{2}$, Cristiani Belmonte ${ }^{2}$, Lorraine Tomim Feroldi ${ }^{1}$, Roberto Cecatto Júnior ${ }^{2}$
}

\author{
${ }^{1}$ Federal University of Paraná - UFPR, Palotina - Paraná - Brazil, street Pioneiro, Number 2153, Zip Code: 85950- \\ 000, Dallas Garden \\ ${ }^{2}$ State University of West Paraná - Unioeste, Marechal Cândido Rondon - Paraná - Brazil, street Pernambuco, \\ Number 1777, Zip Code: 85960-000, Box: 91, Center
}

\section{*Corresaponding author: eloisa-lorenzetti@hotmail.com}

\section{Abstract}

All crops are usually affected by phytosanitary and nutritional problems. It is known that fertilizers can elevate productivity and control of diseases, characteristics that make nutrients indispensable in combating hunger, and can help to reduce the use of fungicides and their negative impact on the environment. There are more than 15 elements considered essential for plants, including calcium, manganese, copper, and zinc, which will be detailed in this study in order to understand how they can affect the control of plant diseases.

Keywords: Phytopathogens. Nutrients. Plant productivity. Disease management.

Introduction

Plants are a food source for people, and their production may be reduced both qualitatively and quantitatively due to the presence of diseases. Management of these diseases is necessary since they can also cause major economic and social losses (Bergamin Filho et al., 2018).

Among the general principles of plant disease control proposed by Whetzel, are protection, which is commonly obtained by the use of fungicides, due to which pathogens are directly affected, and immunization by the use of resistant varieties, which is considered an ideal principle, since it does not affect the cost of production and assists in reducing the environmental impact (Bergamin Filho and Amorim, 2018). Resistance induction can also be included in immunization principles.

According to Bedendo et al. (2018), nutrients can interfere with the two previously mentioned forms, that is, they may predispose the plant to the action of pathogenic agents by modifying its composition and growth, which interferes with their defense mechanisms, or directly alter the microbial activity in the phylloplane and in the rhizosphere.

According to Motter et al. (2012), the nutritional status in which the plants are found is considered to be one of the main factors responsible for defense mechanisms against biotic factors. Lima et al. (2010) suggest that the lack of this balance is also related to the increased severity of certain diseases, which shows that an adequate management seeking the nutritional balance of both macro- and micronutrients may hinder the development of some pathogens (Agrios, 2005).

The use of fungicides has shown efficacy, maintaining the productivity of the crop and decreasing the severity of the main diseases (Ecco et al., 2014). However, according to Leite and Stangarlin (2008), the control of plant diseases in monocultures is very dependent on fungicides, which concerns governmental organisations, which stimulates the search for alternatives with less environmental impact. According to Pascholati et al. (2014), there are many products capable of inducing resistance in plants against pathogens; however, studies on their applicability and possibility of use for this purpose are necessary.

\section{Plant disease control}

Diseases can be controlled in different ways, using various control methods that can act on the plant, environment, or pathogen (Bergamin Filho and Amorim, 2018) and seek to keep their population at baseline levels to ensure a low level of economic damage (Yokoyama, 1996).

Genetic control uses resistant or tolerant plants, which diminishes the disease in an expressive way and is considered ideal, and can be applied in large areas and generate low environmental impact (Camargo, 2018).

Cultural control encompasses agricultural practices that minimize the effects of diseases and can act on both the host and the pathogen (Macena et al., 2011). Examples include the use of healthy seedlings and seeds, elimination of healthy plants and alternative hosts, crop rotation, and elimination of cultural remains (Ventura and Costa, 2006). According to Lanza et al. (2016), the use of resistant cultivars associated with cultural measures, known as phytosanitary management, is usually applied to maize crops. 
Physical control makes use of factors such as refrigeration, heat treatment in soil and in propagation organs, solarization, ionizing radiation, and ultraviolet radiation to control diseases (Bettiol and Ghini, 2003).

Biological control of plant diseases is performed by organisms to reduce the population of pathogens (Bettiol, 1991; Rufino et al., 2018), and contributes to the reduction of the environmental impact (Gaur and Sharmam, 2010).

Chemical control is used at a large scale because it is economically feasible, practical, and efficient (Vida et al., 2004), and is based on the use of organic or inorganic molecules that can be synthesized or are natural (Silva Júnior and Behlau, 2018).

According to Boff (2008), some of these products present high persistence both in the environment and in living beings, which can cause serious contamination in food and lead to risks to the people who manipulate it.

Although there are many forms of disease control, fungicides are used because they are practical, efficient, and economically viable (Duarte et al., 2009). Because of the awareness of the problems caused by the excessive use of fungicides, its use is being sought to reduce, and new forms of disease control have been studied (Morandi and Bettiol, 2009).

The use of alternative methods in disease control is an inexpensive way and is less aggressive to the environment and the health of human beings and animals, because the methods have less impact on biodiversity (Hamerschmidt et al., 2012). They are modern and sophisticated practices that understand the significant complexity of agronomic techniques (Paula Júnior et al., 2016).

The objective of this new vision of control is to hinder the occurrence of phytopathogens at population levels that cause economic damage, rather than using curative measures, which are used only when diseases already occur at economically undesirable levels (Bettiol, 2008).

\section{Nutrients and disease control}

A very important factor for disease control is the nutritional status in which plants are found, because nutritional balance is considered as one of the main factors responsible for defense mechanisms against biotic factors (Motter et al., 2012), and the lack of this balance is also related to the increased severity of certain diseases (Lima et al., 2010).

Thus, adequate management seeking the nutritional balance may hinder the development of some diseases, and when provided adequately, the nutrients are able to increase the reaction capacity of the plant to the pathogen (Bedendo et al., 2018).

Both macronutrients and micronutrients can modify the susceptibility of plants because they act on the vigor and defense reactions of vegetables (Bedendo et al., 2018). According to Bedendo et al. (2018), care should be taken regarding nutrient supply, since both excess and deficiency predispose the plant to attack by pathogens, not only by affecting plant growth and composition, but also by affecting direct microbial activity both in the rhizosphere and in the soil.

According to Marschner (2012), mineral nutrition influences the degree of plant resistance by altering the morphology and histology, or modifying the chemical composition of tissues in response to infection by pathogens. In addition to these factors, the nutritional state of the plant may also interfere with the defense mechanisms, protecting plants through physical barriers that prevent the penetration of hyphae due to thickening of the cuticle or lignification of epidermal cells, thus not allowing the output of sugars and amino acids used in the nutrition of the pathogens. In addition, there is still the production of phenolic compounds with fungistatic properties.

Zambolim and Ventura (2012b) affirmed that when there is equilibrium between the minerals in the plant, there is also an increase in the resistance of the same to the pathogens by means of mechanical barriers (e.g., by lignification) or by the synthesis of antimicrobial compounds (e.g., phytoalexins); that is, although the disease cannot be eliminated completely by a specific nutrient, the severity of this disease can be significantly diminished.

To be considered a nutrient, the element, be it macro or micro, must exert an essential physiological function, that is, its presence must be indispensable for the plant to be able to complete its life cycle (Zanão Júnior, 2012).

More than 15 elements, including calcium, copper, manganese, and zinc, are essential to cultivated plants (Oro et al., 2012, Zambolim and Ventura, 2012b).

\section{Calcium (Ca)}

$\mathrm{Ca}$ is linked to specific enzymatic system functions, and because it affects soil $\mathrm{pH}$, it can result in the modification of the population of antagonistic microorganisms (Motter et al., 2012).

The effect of calcium of lowering the $\mathrm{pH}$ contributes to the reduction of several soil diseases, such as those caused by Rhizoctonia, Sclerotium, Pythium, Botrytis, Fusarium, and Phytophthora, among others. This nutrient also has inhibitory action against fungal toxins or can still make them inactive (Zambolim and Ventura, 2012a).

The calcium contained in plant tissues affects the incidence of diseases when the levels of this element are low or high (Boudsocq et al., 2010). This macronutrient has an effect on the structural stability of the plant tissue, on the movement of metabolites from one cell to the other, on the permeability and selectivity of the membrane, and also acts as a secondary messenger, activating proteins involved in vital biochemical processes, such as calmodulin (Zanão Júnior, 2012).

Many pathogens can reach the plant tissue by the production of extracellular pectolytic enzymes, such as galacturonase, which are responsible for dissolving the lamella media. Galacturonase activity is drastically inhibited in the presence of calcium, favoring the action of the plant against the pathogen (Malavolta, 2008; Morales et al., 2012).

Calcium is one of the components that form the middle lamella, as well as nitrogen. It is important in the management of diseases, and several studies have shown a reduction in both the incidence and severity of various diseases in cultures of high importance (Zambolim and Ventura, 2012a).

\section{Copper (Cu)}

Copper is involved in the metabolism of secondary compounds, and if there is a deficiency of this nutrient, morphological or biochemical alterations may occur, that favor the infection of pathogens (Malavolta, 2008), by the lower lignification of the cell wall and increase the susceptibility of the plants (Viecelli, 2017).

This element has low mobility and is considered as an activator or as a component of enzymes involved in respiration, photosynthesis, and detoxification by free 
radicals or reactive oxygen species by the peroxidase enzyme (Zanão Júnior, 2012). The decrease in the activity of this enzyme leads to accumulation of phenols and reduction of lignification and of melantic substances; thus, the role of copper in secondary metabolism indicates an important function of the element in conferring mechanical resistance against pathogens (Kirkby and Römheld, 2007).

With a higher amount of copper, the peroxidase activity is lesser and the accumulation of phenolic compounds is higher, both of which are toxic to bacteria. A higher amount of copper also leads to more polyphenol oxidase activity, which is responsible for converting phenolic compounds into quinones (Zambolin and Ventura, 2012c).

In addition to being part of the biosynthesis of lignin and alkaloids, copper is part of the biosynthesis of brown melanotic substances that are formed in tissue injuries, which can prevent fungal spore germination and the growth of germinative tubes (Zambolin and Ventura, 2012c).

Thus, it can be verified that copper affects the occurrence of diseases in plants by direct toxic action (antimicrobial), or by affecting plant resistance or pathogen virulence (Zambolin and Ventura, 2012c).

\section{Manganese (Mn)}

Manganese acts as an important cofactor of several key enzymes in the biosynthesis of the secondary metabolites of the plant (Kirkby and Römheld, 2007). In addition, it is involved in numerous physiological processes, such as protection against the entry of pathogens. Thus, the deficiency of this micronutrient reduces the defense against the entry of phytopathogens (Malavolta, 2008), which can partly be the cause of the greater susceptibility to diseases in plants deficient of this micronutrient (Kirkby and Römheld, 2007).

In the protection against the entry of pathogens, manganese acts mainly in the synthesis of lignin and phenolic compounds (Morales et al., 2012), interfering at the onset of infection (Malavolta et al., 1997).

Manganese has low mobility in plants and plays a role in the functioning and multiplication of chloroplasts, in photosynthesis, and in regulation of hormones. It is a cofactor of more than 35 enzymes, in addition to acting in the synthesis of phenolic compounds and proteins, and protects cells from the effects of free radicals (Zanão Júnior, 2012). Regarding plant protection, it is the micronutrient that has the greatest association with the mechanisms of plant resistance against pathogens and is involved in the synthesis of phenolic compounds and lignin. It also acts as an activator of enzymes such as phenylalanine ammonia-lyase, and phenolic compounds such as phytoalexins, tannins, and flavonoids, in addition to its participation as a peroxidase cofactor (Zanão Júnior, 2012).

In addition, this micronutrient may influence the growth, sporulation, reproduction, and synthesis of enzymes and toxins by pathogens. It may cause inhibition of exoenzymes used by fungi to deforest the cell wall and may have direct toxic effects by not allowing microbial growth (Zanão Júnior, 2012).

For corn crops, according to Borges et al. (2009), manganese is considered the second most relevant micronutrient based on nutritional demand. Thus, it is very important that great emphasis be given to it in order to avoid possible disability (Gott et al., 2014).

\section{Zinc (Zn)}

Zinc affects plant growth and is present in several enzymes that affect respiration and processes linked to the metabolism of carbohydrates and proteins (Motter et al., 2012).

There is significant evidence that zinc, by maintaining the structure and integrity of the plasmatic membrane and controlling the permeability, also protects the plant against various pathogens. When this micronutrient is deficient, the membranes become permeable, and the carbohydrates and amino acids are released, attracting pathogens for both the roots and shoots of the aerial part of the plant (Kirkby and Römheld, 2007; Zanão Júnior, 2012).

Zinc has low mobility in plants and is responsible for regulating the activity of several enzymes because it is a structural cofactor, besides affecting the synthesis of proteins and auxin (Zanão Júnior, 2012). It also acts directly on the pathogen and is essential for sporulation and virulence of several species belonging to the genus Fusarium, with the reduction of root diseases in tomato, charcoal rot in maize, potato, and root wilt in avocado, among others (Zambolin and Ventura, 2012c).

\section{Final considerations}

Even if the disease is not completely controlled, nutrients in a balanced quantity can contribute to the elevation of the plant's resistance level. In addition, they can act directly on the pathogens or the environment, disfavoring them. Thus, even if complete elimination of the disease does not occur, the occurence of the disease is decreased.

Mineral nutrition can also contribute to a decrease in the use of fungicides by assisting in the control of diseases, whereas it is an essential component in the integrated control of plant health.

The type of pathogen, the species and variety of the host plant, the type of soil in which their interaction takes place, climate of the region, weather, nutrient application mode, and other various factors, have an influence on the mineral nutrition of the plants and how the nutrients act in the most diverse situations and sites in which they occur.

In view of this, in-depth studies encompassing such situations should be carried out in order to obtain results that can help in the comprehension of the most varied situations and their relationships with the nutrients and diseases of the plants, which impair plant productivity.

\section{References}

Agrios GN (2005) Plant pathology. 5th ed San Diego: Elsevier Academic Press. 207- 248.

Bedendo IP, Amorim L, Mattos-JR D (2018) Ambiente e doença. In: Amorin L., Rezende JAM, Bergamin Filho A. Manual de fitopatologia: princípios e conceitos. 5. Ed. Ouro Fino: Ceres, 1: 93-103.

Bergamin Filho A, Amorin L (2018) Princípios gerais de controle. In: Amorin L., Rezende JAM, Bergamin Filho A. Manual de fitopatologia: princípios e conceitos. 5. Ed. Ouro Fino: Ceres, 1: 215-228.

Bergamin Filho A, Amorin L, Rezende JAM (2018) Importância das doenças de pantas. In: Amorin L., Rezende JAM, Bergamin Filho A. Manual de fitopatologia: princípios e conceitos. 5. Ed. Ouro Fino: Ceres, 1: 15-25. 
Bettiol W (1991) Controle biológico de doenças de plantas. Jaguariúna. Centro Nacional de Defesa da Agricultura/EMBRAPA.

Bettiol W (2008) Conversão de sistemas de produção. In: Poltronieri, L.S.; Ishida, A.K.N. Métodos alternativos de controle de insetos-praga, doenças e plantas daninhas: panorama atual e perspectivas na agricultura. Belém, PA: Embrapa Amazônia Oriental, 289-308.

Bettiol W, Ghini R (2003) Controle físico de doenças e de plantas invasoras. In: Campanhola, C, Bettiol W. Métodos alternativos de controle fitossanitário. Jaguariúna, Embrapa Meio Ambiente, 165-189.

Boff P (2008) Agropecuária saudável: da prevenção de doenças, pragas e parasitas à terapêutica não residual. Lages: UDESC. $80 \mathrm{p}$.

Borges ID, Pinho RG VON, Pereira JLAR (2009) Acúmulo de micronutrientes em híbridos de milho em diferentes estádios de desenvolvimento. Ciência e Agrotecnologia 33(4): 1018-1025.

Boudsocq M, Willmann M.R, Mccormack M, Lee H, Shan L, He P, Bush J, Cheng SH, Sheen J (2010) Differential innate immune signalling via $\mathrm{Ca}^{2+}$ sensor protein kinases. Nature. 464(7287): 418-422.

Camargo LEA (2018) Genética da interação patógenohospedeiro. In: AMORIN L, Rezende JAM, Bergamin Filho A. Manual de fitopatologia: princípios e conceitos. 5. Ed. Ouro Fino: Ceres, 1: 85-92.

Duarte RP, Juliatti FC, Freitas, PT de (2009) Eficácia de diferentes fungicidas na cultura do milho. Biosc J. 25(4): 101-111.

Ecco M, Rosset JS, Rampim L, Costa ACT, Lana MC, Stangarlin JR, Sarto MVM. Características agronômicas de híbridos de milho segunda safra submetidos à aplicação de fungicida. Rev Agrar. 7(26): 504-510.

Gaur RB, Sharmam RN (2010) Biocontrol of root rot in cotton and compatibility of potential bioagents with fungicides. Indian Journal of Plant Protection, 38: 176-182.

Gott RM, Aquino LA, Carvalho AMX, Santos LPD, Nunes PHMP, Coelho BS (2014) Índices diagnósticos para interpretação de análise foliar do milho. Rev Bras Enge Agr Amb. 18(11): 1110-1115.

Hamerschmidt I, Toledo MV, Popia AF, Assis O (2012) Manual de olericultura orgânica. Curitiba: Emater. 129 p.

Kirkby EA, Romheld V (2007) Micronutrientes na fisiologia de plantas: Funções, absorção e mobilidade funções, absorção e mobilidade. International Plant Nutrition Institute. Encarte Técnico, n.118, 24 p.

Lanza FE, Zambolim L, Costa RV, Silva DD, Queiroz VAV, Parreira DF, Mendes SM, Souza AGC, Cota LV (2016) Aplicação foliar de fungicidas e incidência de grãos ardidos e fumonisinas totais em milho. Pesquisa Agropecuária Brasileira, Brasília, 51(5): 638-646.

Leite B, Stangarlin JR (2008) Fisiologia e bioquímica de doenças fúngicas. In: Pascholati, S.F.; Leite, B.; Stangarlin, J.R.; CIA, P. Interação planta-patógeno: fisiologia, bioquímica e biologia molecular. Piracicaba: FEALQ, 1:115152.

Lima LM, Pozza EA, Torres HN, Pozza AAA, Salgado M, Pfenning LH (2010) Relação nitrogênio/potássio com mancha de Phoma e nutrição de mudas de cafeeiro em solução nutritiva. Trop PI Path. 35: 223-228.

Macena AMF, Canteri MG, Ferrieira Júnior JP (2011) Espaçamento e manejo de restos culturais para o controle de Sclerotinia sclerotiorum em feijoeiro. Cien Rur. 41(11): 1871-1873.
Malavolta E (2008) O futuro da nutrição de plantas tendo em vista aspectos agronômicos, econômicos e ambientais. Informações agronômicas. International Plant Nutrition Institute. n.121. Disponível em: <https://www.ipni.net/ppiweb/brazil.nsf/87cb8a98bf7257 2b8525693e0053ea70/d20fb44d85259bf70325725300628 70e/\$file/jornal-121.pdf> Acesso em: 24/03/2017.

Malavolta E, Vitti GC, Oliveira SA (1997) Avaliação do estado nutricional das plantas: princípios e aplicações, 2 ed. Piracicaba: POTAFOS, 319p.

Marschner H (2012) Mineral nutrition of higher plants. New York: Academic Press, 3. ed. London: Elsevier, 643 p.

Morales RGF, Santos I, Tomazeli VN (2012) Influência da nutrição mineral foliar sobre doenças da parte aérea da cultura do trigo. Rev Cer. 59(1): 71-76.

Morandi MAB, Bettiol W (2009) Controle Biológico de Doenças de Plantas no Brasil. In: Biocontrole de Doenças de Plantas: Uso e Perspectivas. Jaguariúna: Embrapa Meio Ambiente, 7-14.

Motter A, Giongo L, Rossono ME, Meneghetti ML, Matos RE, Oliveira RC (2012) Nutrição mineral e a incidência de patógenos em plantas. In: Viecelli, C.A.; Moreira, G.C.; Oliveira, R.C.; Simonetti, A.P.M.M.; Santos, R.F. Nutrição mineral e a incidência de doenças em plantas. Cascavel: ASSOESTE, 15-30.

Oro O, Silva CAT, Dias-Arieira CR (2012) Indução de resistência a doenças na cultura da soja. J Agron Sci. 1(1): 148-154.

Pascholati SF, Melo TA, Brand SC, Rezende DC, Nogueira Júnior AF, Silva Júnior MB, Resende MLV (2014) Indução de resistência no controle de fitopatógenos: registro de indutores e uso comercial no Brasil. In: Schwan-Estrada KRF, Silva CM, Maia AJ, Faria CMDR, Colella JCT. Indução de resistência em plantas a patógenos. Maringá: UEM/MPA, 233-253.

Paula Júnior TJ, Morandi MAB, Venzon M (2016) Manejo integrado de doenças e pragas utilizando o controle biológico. In: Halfeld-Vieira B.A, Marinho-Prado JS, Nechet $\mathrm{KL}$, Morandi MAB, Bettiol W (Eds) Defensivos agrícolas naturais: uso e perspectivas. Brasília, DF: Embrapa. 214237.

Rufino CPB, Araujo CS, Nogueira SR (2018) Desafios na utilização do controle biológico de doenças de plantas na Amazônia. J Bas Educ. (1): 262-248.

Silva Júnior GJ, Behlau F (2018) Controle químico. In: Amorin, L.; Rezende, J.A.M.; Bergamin Filho, A. Manual de fitopatologia: princípios e conceitos, $5^{\text {a }}$ ed. Ouro Fino: Ceres, 1: 239-260.

Ventura JA, Costa, H (2006) Controle cultural. In: Oliveira SMA, Terao D, Dantas SAF, Tavares SCCH. Patologia póscolheita: frutas, olerícolas e ornamentais tropicais. Brasília: Embrapa Informações Tecnológicas, 145-169.

Viecelli, C.A (2017) Guia de deficiências nutricionais em plantas. Toledo: ASSOESTE, $112 \mathrm{p}$.

Vida JB, Zambolim L, Tessmann DJ, Brandão Filho JUT, Verzignassi JR, Caixeta MP (2004) Manejo de Doenças de Plantas em Cultivo Protegido. Fit Bras. 29(4): 355-372.

Yokoyama M. (1996) Principais pragas e seu controle. In: Araujo RS, Rava CA, Stone LF, Zimmermann MJO. Cultura do feijoeiro comum no Brasil. Piracicaba: Potafós. 786 p.

Zambolim L, Ventura JA (2012a) Mecanismo de ação do cálcio na interação com doenças de plantas. In: Zambolim, L, Ventura JA, Zanão Júnior LA. Efeito da nutrição mineral no controle de doenças de plantas. Viçosa: Universidade 
Federal de Viçosa Departamento de fitopatologia, 1: 137163.

Zambolim L, Ventura JA (2012b) Mecanismos gerais dos nutrientes sobre a severidade de doenças de plantas. In: Zambolim, L.; Ventura, J.A.; Zenão Júnior, L.A. Efeito da nutrição mineral no controle de doenças de plantas. Viçosa: Universidade Federal de Viçosa Departamento de fitopatologia, 1: 25-45.
Zambolim L, Ventura JA (2012c) Mecanismos de ação de micronutrientes na interação com doenças de plantas. In: Zambolim L, Ventura, JA, Zanão Júnior LA. Efeito da nutrição mineral no controle de doenças de plantas. Viçosa: Universidade Federal de Viçosa Departamento de fitopatologia, 1: 199-236.

Zanão Júnior LA (2012) Importância e função dos nutrientes no crescimento e desenvolvimento de plantas. In: Zambolim L, Ventura JÁ, Zanão Júnior LA. Efeito da nutrição mineral no controle de doenças de plantas. Viçosa: Universidade Federal de Viçosa Departamento de fitopatologia. 1: 3-21. 